\title{
Activity of 70\% Ethanol Extract of Chrysophyllum cainito in Increasing Vertebrae Trabecular Bone Density in Female Mice
}

\author{
Nur Imamah Utaminingtyas', Burhan Ma'arif2", Dewi Sinta Megawati², \\ Ria Ramadhani Dwi Atmaja ${ }^{2}$ \\ ${ }^{1}$ Undergraduate Student of Department of Pharmacy, Faculty of Medical and Health Science, Maulana Malik \\ Ibrahim State Islamic University, Malang \\ ${ }^{2}$ Department of Pharmacy, Faculty of Medical and Health Science, Maulana Malik Ibrahim State Islamic \\ University, Malang
}

\begin{abstract}
Phytoestrogens are a class of compounds that have estrogen-like functions or structure. This research was conducted to find out the phytoestrogens activity in Chrysophyllum cainito leaves, in increasing the vertebrae trabecular bone density of female mice, using dexamethasone induction as osteoporosis model. The $70 \%$ ethanol extract of $C$. cainito leaves was given to female mice with dose of 100 ; 200; and $400 \mathrm{mg} / \mathrm{kgBW}$ mice/day after being induced orally with dexamethasone with $0.145 \mathrm{mg} / \mathrm{kgBW}$ mice/day. The positive control used was $1.3 \mathrm{mg} / \mathrm{kgBW}$ mice/day alendronate. This research had been done in four weeks. The increasing of trabecular vertebrae bone density of female mice was measured with Histomorphometry staining methods. The result showed the $70 \%$ ethanol extract of $C$. cainito leaves have activity in increasing trabecular vertebrae bone density for female mice with optimum dose of 400 $\mathrm{mg} / \mathrm{kgBW}$ mice/day. This activity occurs because phytoestrogens content in $70 \%$ ethanol extract of $C$. cainito leaves, that may replace the function of estrogen in its bond with ER.
\end{abstract}

Key words: Phytoestrogen; Crysophyllum caimito; Flavonoid; Osteoporosis

\section{INTRODUCTION}

Osteoporosis is a condition of bone mass degradation along with microarchitecture damage which causes improvement of bone fracture risk (Ahmed and Elmantaser, 2009; Agrawal and Gupta, 2013). The microarchitecture damage in bone tissue is related tightly to the existence of turnover abnormality in the bone remodeling process, that creates unbalanced of bone formation and resorption process (Kini and Nandeesh, 2012; Lee et al., 2013; Meeta, 2013). Estrogen deficiency is known as one of important factor that creates bone remodeling unbalance process for postmenopausal woman (Lee et al., 2013; Dipiro et al., 2008), and hormone replacement therapy (HRT) is a medical treatment which mostly recommended for osteoporosis in postmenopausal woman (Rachman et al., 2004). Unfortunately, giving HRT in long-term therapy can create a potential side effect such as coronary event, venous thromboembolism, stroke, breast cancer, and dementia (Constantine and Pickar, 2005; Wibowo, 2009; Lee et al., 2013).

Phytoestrogens are a class of compounds from the plant that can substitute the estrogen

\footnotetext{
*Corresponding author : Burhan Ma'arif

Email : burhan.maarif@farmasi.uin-malang.ac.id
}

function in its bound with estrogen receptor. Instead of easily found in plants and does not have the side effect, the phytoestrogens group were also reported to have benefits to increase the bone mass (Urasopon et al., 2008; Villiers, 2009; Yang et al., 2012). Then, it becomes the potential alternative medical treatment for postmenopausal woman (Yang et al., 2012). Chrysophyllum cainito was known as plant which contains phytoestrogens. C. cainito grow a lot in East Java, Indonesia. People use its fruit to be consumed as food. However, this plant has not been widely studied. One of the studies showed the $70 \%$ ethanol extract of $C$. cainito leaves contained polyphenol, flavonoid, isoflavone, tannin, sterol, and triterpenoid compound group (Luo et al., 2002; Koffi et al., 2009). Isoflavone, sterol, and triterpenoid are compound which has an estrogenic activity that is included in the phytoestrogens compound.

To know the phytoestrogens activity of $C$. cainito leaves in fixing bone remodeling process, the mice (Mus musculus) trabecular vertebrae bone density level measurement was done by giving the treatment of $70 \%$ ethanol extract of $C$. cainito leaves, then the measurement of mice bone density level was done by histomorphometry and HE methods. 


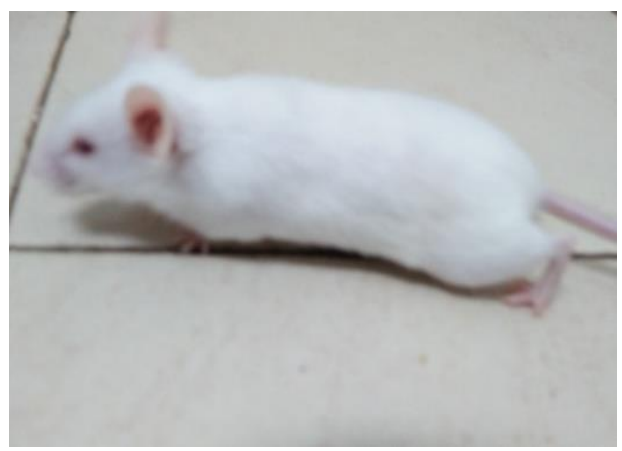

(a)

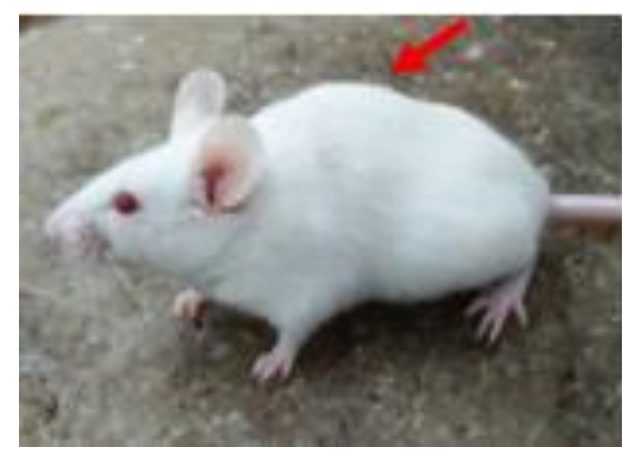

(b)

Figure 1. Normal mice. (a) and mice with osteoporosis; (b) The change of vertebrae posture becomes kyphotic is shown by arrows.

\section{METHODOLOGY \\ Materials \\ Plant Material}

C. cainito was taken and identified in UPT Materia Medica, Batu, Indonesia in July 2017 with specimen number $1 b-2 b-3 b-4 b-6 b-7 b-9 b-10 b-$ 11b-12b-13b-14a-15a-109b-119b-120a-121b124b-125a-126b-127a. The fresh leaves were dried and grinded to produce green leaves powder.

\section{Chemical}

The 70\% ethanol (Merck), dexamethasone (Kimia Farma), alendronate (Novel), CMC Na 0.5\% and chloroform (Merck) were purchased from Phytochemistry Laboratory in Pharmacy Department, Faculty of Medical and Health Science, Maulana Malik Ibrahim State Islamic University, Malang. The $10 \%$ formalin, $10 \%$ formic acid, $70 \%$ alcohol, $3 \%$ nitrate acid, acetone, $1.5 \%$ xylol, liquid paraffin, glycerin, ammonia solution, hematoxylin and eosin dye were acquired from Histology Laboratory, Faculty of Medicine, Universitas Airlangga, Surabaya.

\section{Methods}

\section{Sample Preparation}

C. cainito leaves were extracted with $70 \%$ ethanol with ultrasonic assisted extraction methods, and were prepared to produce extract suspension in aquadest with dose 100; 200; and $400 \mathrm{mg} / \mathrm{kgBW}$ mice/day. Dosage one was made by mixing $280 \mathrm{mg}$ extracts to $50 \mathrm{ml} \mathrm{CMC} \mathrm{Na} 0.5 \%$. Dosage two was made by mixing $560 \mathrm{mg}$ extract to $50 \mathrm{ml} \mathrm{CMC} \mathrm{Na} \mathrm{0.5 \% .} \mathrm{Dosage} \mathrm{three} \mathrm{was} \mathrm{made} \mathrm{by}$ mixing $1120 \mathrm{mg}$ extract to $50 \mathrm{ml} \mathrm{CMC} \mathrm{Na} 0.5 \%$.

\section{Treatment}

Female mice were induced with dexamethasone of $0.145 \mathrm{mg} / \mathrm{kgBW}$ mice/day orally. Then each group was treated with $100 ; 200$; and $400 \mathrm{mg} / \mathrm{kgBW}$ mice/day samples, and 1.3 $\mathrm{mg} / \mathrm{kgBW}$ mice/day alendronate as positif control. It had been given in four weeks orally for five groups (contains six mice in each group). The next step was mice surgery to take the trabecular vertebrae bone. The vertebrae bone was cut in thorax part and put inside the bottle with $10 \%$ formalin. Trabecular vertebrae bone then inserted in decalcification solution (7.0g aluminum chloride, $8.5 \mathrm{~g}$ chloride acid, and $5.0 \mathrm{ml}$ formic acid in $100 \mathrm{ml}$ water) and then the density were tested. Neutralization was done using sodium sulfate $2 \%$ for 24 hours. Trabecular vertebrae bone then washed using water for 12 hours and rinsed with $70 \%$ alcohol. The bone then blocked with paraffin and cut with microtome. Next step was hydration with $70 \%$ alcohol and hematoxylin as the main dye. The bone was inserted in $1 \%$ acid alcohol and ammonia solution, and was added with $1 \%$ eosin. The final step was clearing the bone with $1.5 \%$ xylol, and plated on object glass. The observation slide was analyzed using an Olympus Cellsens program with $100 \mathrm{x}$ zoom.

\section{Data Analysis}

The research result was analyzed using oneway ANOVA with a significance value of 0.05 ( $p \leq$ 0.05 ). If there was any difference then would be tested by using post hoc testing with LSD to test the difference and average of the treatment.

\section{RESULTS AND DISCUSSION}

Extraction of $C$. cainito leaves with $70 \%$ ethanol produces extracts with yield value of $13.92 \%$. Osteoporosis was created with dexamethasone induction of $0.145 \mathrm{mg} / \mathrm{kgBW}$ mice/day orally for female mice. Mice with osteoporosis could be distinguished from healthy mice by looking at their crooked back (kyphotic) (Figure 1). 


\section{Burhan Ma'arif}

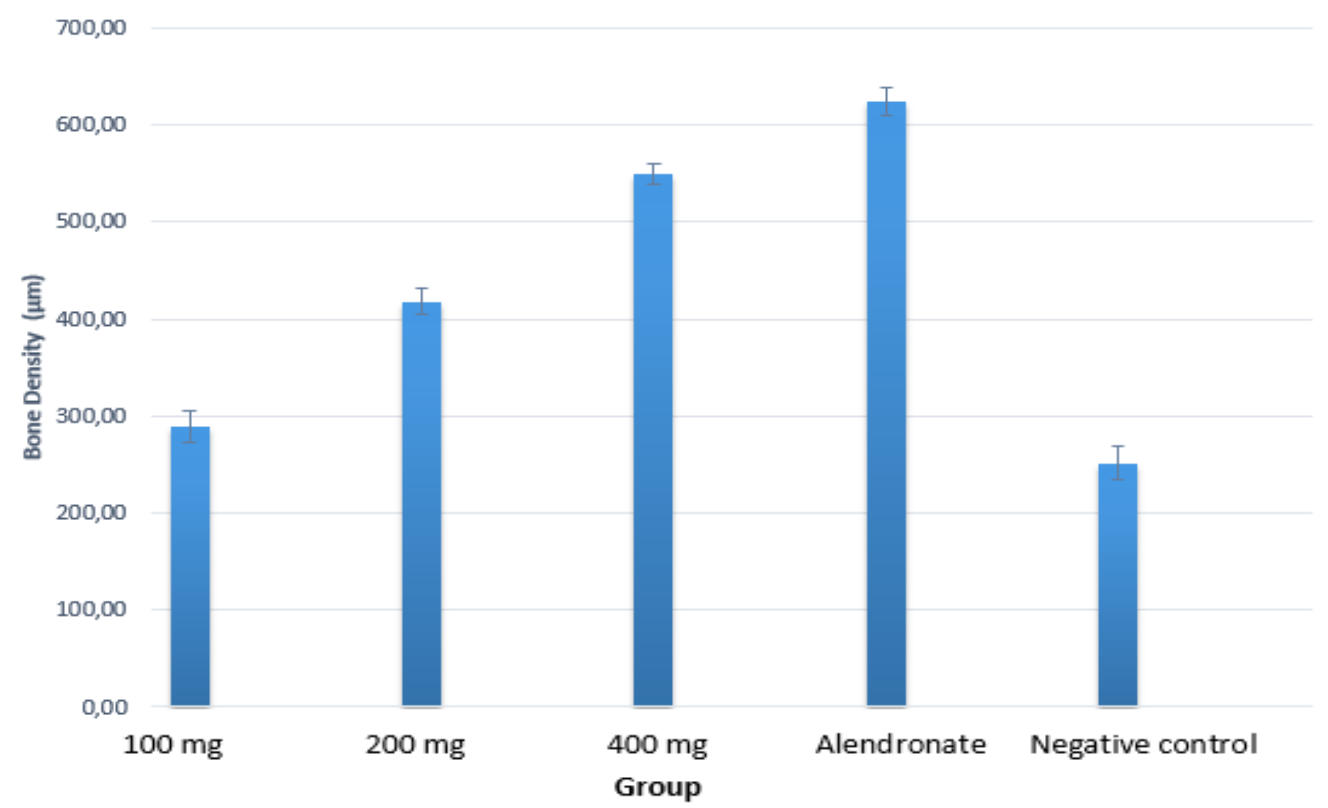

Figure 2. Bone density values of each group.

Table I. Bone Improvement Percentage

\begin{tabular}{lc}
\hline \multicolumn{1}{c}{ Groups } & Bone Improvement Percentage \\
\hline C. cainito etanol extract dose $100 \mathrm{mg} / \mathrm{kgBW}$ mice/day & $14.92 \%$ \\
C. cainito etanol extract dose $200 \mathrm{mg} / \mathrm{kgBW}$ mice/day & $66.22 \%$ \\
C. cainito etanol extract dose $400 \mathrm{mg} / \mathrm{kgBW}$ mice/day & $118.66 \%$ \\
Positive Control (Alendronate $1.3 \mathrm{mg} / \mathrm{kgBW}$ mice/day) & $147.93 \%$ \\
\hline
\end{tabular}

Dexamethasone is one of the synthetic corticosteroids. By treatment this medicine for four weeks for mice, is equal to 3-4 years treatment for humans (Brunton et al., 2005; Noor, 2014). The use of corticosteroid group compounds for a longterm period (3-6 months, or more) can cause the inhibition of bone formation process (Kemenkes RI, 2015). The use of glucocorticoid for long term also can reduce the level of estrogen and progesterone hormone, while the deficiency of estrogen is considered as one factor that causes the imbalance of bone remodeling process and has a role in increasing bone resorption process (Dipiro et al., 2008). Figure 2 shows the average result of trabecular vertebrae bone density for each group, whereas (Table I) shows percentage of bone density improvement of trabecular vertebrae compared to negative control.

Homogenity test of mice's bone density with $p>0.05$ showed that average data of bone density in the experimental group had a similar variant (homogenous). Normality test of average data of mice's bone density in each group with $\mathrm{p}>0.05$, showed that the data was normally distributed. Therefore, it fulfilled the parametric statistics test qualification of one-way ANOVA.
In one-way ANOVA statistical test, the significance level was $\mathrm{p}<0.05$. It showed that there was a minimal difference between a pair of the experimental group. To know the significant difference of experimental group, post hoc test was done using the LSD method. The LSD test result showed the significant difference between the bone density value of the treatment group with the dosage of 200 and $400 \mathrm{mg} / \mathrm{kgBW}$ mice/day compare to the negative negatif control group with p-value 0.011 and 0.001 . It showed that $70 \%$ ethanol extract of $C$. cainito leaves in that dosage could increase bone density. While for the extract with dosage of $100 \mathrm{mg} / \mathrm{kgKg}$ mice/day with $\mathrm{p}$ value $=0.277$ could not increase the bone density, because there was no significant difference with the negative control group. LSD test result showed the significant difference between two treatment groups $100 \mathrm{mg} / \mathrm{kgBW}$ mice/day and 200 $\mathrm{mg} / \mathrm{kgBW}$ mice/day mice/day with alendronate group with $\mathrm{p}$ value each is 0.000 and 0.007 . Meanwhile, for extract with the dose of 400 $\mathrm{mg} / \mathrm{kgBW}$ mice/day showed that $70 \%$ ethanol extract of $C$. cainito leaves on that dosage did not have significant difference compare to alendronate group with $p$ value 0.139 . 


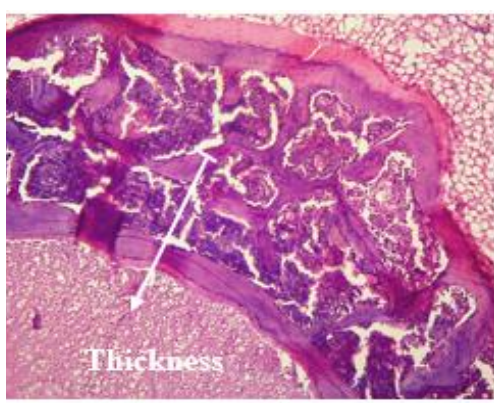

(a)

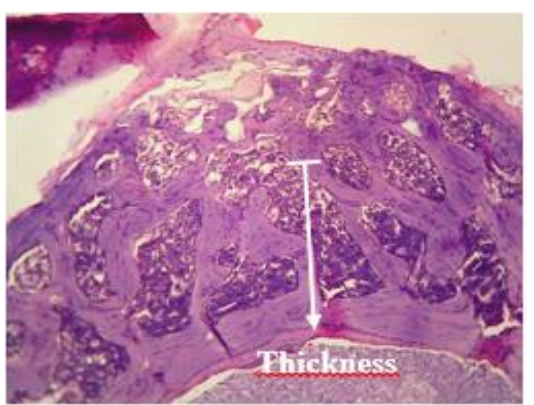

(b)

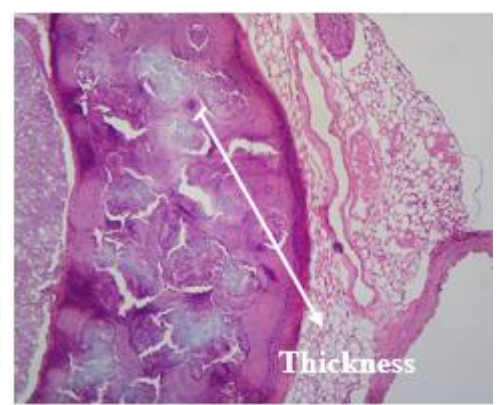

(c)

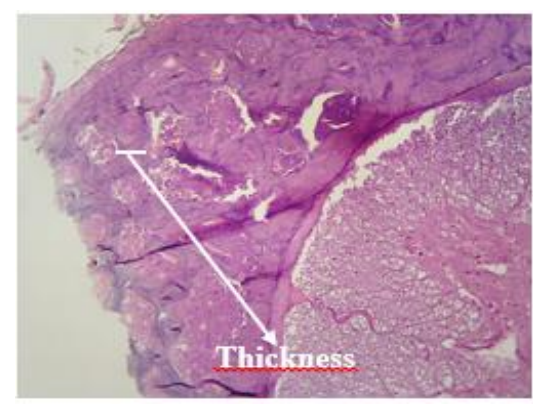

(d)

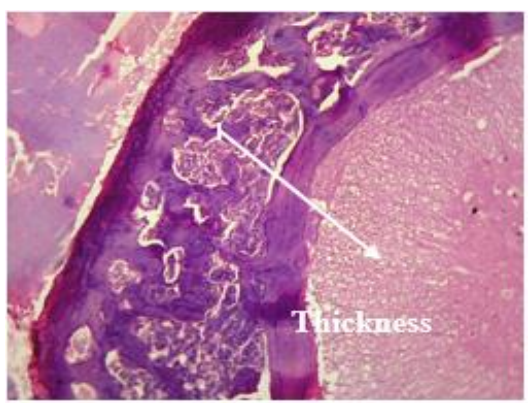

(e)

Figure 3. Histopathology of female mice's vertebrae trabecular bone; (a) Extract of $C$. cainito leaves 100 mg; (b) Extract of $C$. cainito leaves $200 \mathrm{mg}$; (c) Extract of $C$. cainito leaves $400 \mathrm{mg}$; (d) Alendronate; and (e) Negative Control

The result showed the tendency of improvement of trabecular vertebrae bone density value by giving $70 \%$ ethanol extract of $C$. cainito leaves. According to LSD test result, it was found that $70 \%$ ethanol extract of $\mathrm{C}$. cainito leaves with dosage of $100 \mathrm{mg} / \mathrm{kgBW}$ mice/day did not have pharmacology effect. Dosage of $200 \mathrm{mg} / \mathrm{kgBW}$ mice/day could give pharmacology effect by increasing bone density, and for the dosage of 400 $\mathrm{mg} / \mathrm{kgBW}$ mice/day had activity level that was almost equal with alendronate in increasing bone density.

The histopathology check was done and showed in Figure 3. The cancellous bone ( $\mathrm{x}$ ) and solid bone $(y)$ were shown in different colors. There were alpha and beta estrogen receptor $(\mathrm{ER} \alpha$ and $\operatorname{ER} \beta$ ) expressions in bone, which had a role in maintaining homeostasis of bone density. In the situation of estrogen deficiency, which was caused by dexamethasone induction, there was no estrogen binding with ER. Therefore, it caused proosteoclastogenesis cytokines such as Tumor Necrosis Factor-Alpha (TNF- $\alpha$ ), Interleukin-1 (IL1) and Interleukin-6 (IL-6) produced in high number. The production of this cytokines would induce preosteoclast differentiation to mature osteoclast, and would occur massive bone resorption process. Moreover, the increase of cytokines also would inhibit preosteoblast differentiation to mature osteoblast, which then headed to the inhibition of bone formation process. Insulin-like Growth Factor-1 (IGF-1) and Insulin-like Growth Factor-2 (IGF-2) in high number. The decreasing of growth factor could increase osteoclastogenesis and inhibit osteoblastogenesis, so that the osteoporosis tended to occur (Kawiyana, 2009; Kini and Nandeesh, 2012; Meeta, 2013).

In this research, the increasing of trabecular vertebrae bone density for female mice could occur because of phytoestrogens content in $70 \%$ ethanol extract of $C$. cainito leaves. The phytoestrogens compound were bind to ER in cell nucleus and reserved the situation that happened in estrogen deficiency (Yang et al., 2012). Phytoestrogen binding with ER caused the decreasing of osteoclastogenesis and bone resorption, as well as the increasing of osteoblastogenesis and bone formation (Laswati et al., 2015).

\section{CONCLUSION}

The 70\% ethanol extract of $C$. cainito leaves have activity in increasing trabecular vertebrae bone density for female mice with optimum dose of $400 \mathrm{mg} / \mathrm{kgBW}$ mice/day. This activity can occur because phytoestrogens content in $70 \%$ ethanol 
extract of $C$. cainito leaves, that can replace the function of estrogen in its bond with ER.

\section{REFERENCES}

Agrawal V and Gupta. 2013. Recent Update On Osteoporosis. Int J Med Sci Public Health. II (2): 164-168.

Ahmed SF and Elmantaser M. 2009. Secondary Osteoporosis. Endocr Dev, 2009; 16 (90): 170.

Brunton LL. 2005. The Pharmacological Basis of Therapeutics. Goodman \& Gilman's. McGraw-Hill, San Diego,.

Constantine, G. D. and Pickar, 2003. J. H. Estrogens in postmenopausal woman: recent insights. Elsevier : Pharmacology. 3 : 626-634.

Dipiro, J. T., Robert, L. T., Gary, C. Y., Barbara G. W. L., Michael, L. 2008. Pharmacotherapy (A pathophysiologic Approach), 7th Edition. United Stated : McGraw-Hill Companies, Inc.

Edwards, B. J., Brooks, E. R., Langman, C. B. 2004. Osteoporosis Screening of Postmenopausal Woman in the Primary Care Setting: A CaseBased Approach. Gender Medicine, 1 (2).

Kawiyana, IKS. 2009. Osteoporosis Patogenesis Diagnosis dan Penanganan Terkini. J. Peny Dalam, 10 (2): 166.

Kementrian Kesehatan RI. 2015. Indofatin Data dan Kondisi Penyakit Osteoporosis di Indonesia. Pusat data dan Informasi Kemenkes RI, Jakarta.

Kini U and Nandeesh BN. 2012. Physiology of Bone Formation, Remodeling, and Metabolism Springer : Radionuclide and Hybrid Bone Imaging.

Koffi N, Amoikon KE, Tiebre MS, Kadja B, and Zirihi GN. 2009. Effect of Aqueous Extract of Chrysophyllum cainito Leaves on The Glycaemia of Diabetic Rabbits. African Journal Pharmacy Pharmacology, 3 (10): 501-506.

Laswati, H., Agil, M., Widyowati, R. 2015. Effect of Spilanthes acmela and Exercise on
Osteoblast Cells Femur in Mice Dexamethasone Induced. Media Litbangkes 25 (1): 43-50.

Lee WL, Tsui K, Seow KM, Cheng MH, Su WH, Chen CP, Wang PH. 2013. Hormone therapy for postmenopausal woman and unanswered issue. Elsevier : Gynecology and Minimally Invasive Therapy, 2: 13-17.

Luo XD, Basile, MJ, and Kennely, EJ. 2002. Polyphenolic Antioxidants from Chrysophyllum cainito L. (Star Apple). Journal of Agricultural and Food Chemistry, 50 (6): 1379-1382.

Meeta. 2013. Postmenopause Osteoporosis basic and Clinical Consepts. Jaypee Brothers Medical Publishers, New Delhi, 20-22

Noor Z. 2014. Buku Ajar: Osteoporosis Patofisiologi dan Peran Atom Mineral dalam Manajemen Terapi. Salemba Medika, Jakarta.

Rachman, I. A., Soewondo, P., Setiati, S., Kusumawijaya, K., Baziad, A., Witjaksono, J., Sukarya, W. S., Silvia. 2004. Terapi Sulih Hormon pada Wanita Perimenopause. HTA Indonesia.

Urasopon N, Hamada Y, Cherdshewasart W and Malaivijitnond S. 2008. "Preventive effects of Pueraria mirifica on bone loss in ovariectomized rats," Maturitas, 59 (2): 137-148.

Villiers TJ. 2009. Bone health and osteoporosis in postmenopausal woman. Elsevier : Best Practice \& Research Clinical Obstetrics and Gynaecology, 23: 73-85.

Wibowo A. 2009. Cerdas Memilih Obat dan Mengenali Penyakit. PT. Lingkar Pena Kreativa, Jakarta Selatan.

Yang, T-S., Wang, S-Y., Yang, Y-C., Su, C-H., Lee, F-K., Chen, S-C., Tseng, C-Y., Jou, H-J., Huang, J-P., Huang, K-E. 2012. Effects of standardized phytoestrogen on Taiwanese menopausal woman. Elsevier : Taiwanese Journal of Obstetrics \& Gynecology, 51: 229-235. 